DOI:10.17951/h.2015.59.3.59

\begin{tabular}{lcc}
\hline \multicolumn{3}{c}{ A N N A L E S } \\
UNIVERSITATIS & MARIAE CURIE-SKŁODOWSKA \\
LUBLIN - POLONIA & \\
VOL. XLIX, 3 & SECTIOH H \\
\hline
\end{tabular}

Lviv Polytechnic National University, Department of Marketing and Logistics

\author{
OLEH KARYY \\ NAZAR HLYNSKYY \\ oleh_k@mail.ua
}

\title{
Problems and Prospects of the Formation of a Mutual Tourism Product of Local Communities
}

Problemy i perspektywy powstania wspólnych produktów turystycznych dla lokalnych społeczności

Keywords: tourism product, partnership of local authorities, competition, local economic development. Słowa kluczowe: produkt turystyczny, partnerstwo władz lokalnych, konkurencja, lokalny rozwój gospodarczy.

JEL Code: R19

\section{Introduction}

In recent years the influence of local authorities on the economic development on both local and global scales has been becoming more and more appreciable. The contemporary approach to the development of local communities, which is based on the effective usage of a tourism potential (Saak et al., 2012), considers territories of communities as a tourism area, that is to say, territories with special natural, climatic, touristic and recreational resources, in which there are economic and social interrelations between business entities, different population groups, authority, and tourists concerning the usage of tourism products.

Nonetheless, the self-dependence obtained by local authorities particularly in management of economic processes at the local level should not be defined as the total isolation of an economic system of a region/town/village from processes emerging in 
adjacent territories and, consequently, as the lack of coordination between interests of adjacent territorial communities.

Management of a tourism sector at regional level is related to the necessity of taking into consideration objective contradictions (developed by authors on the basis of: Ordzhonikidze, 2014, pp. 60-65; Zviagina and Ismailova, 2014, pp. 30-32; Kotova and Valeshchuk, 2014, p. 49):

- a demand for the creation of equal competitive conditions for enterprises of a region and the simultaneous reduction of access of outsiders to a tourism resource of the region;

- enhancement of competitiveness of small producers in a case of the necessity to increase number and completeness of services provided for tourists;

- preservation and development of the recreational potential in a region in terms of the increase of recreational resources usage and the accessibility of monuments;

- increase of tourism product value in terms of the purchasing power stability of local population;

- coordination of interests of a region with interests of some local communities and the state in general.

The sense of one of the most important properties of new modifications applied to the local development is the appearance of new territorial quasi-formations instead of a town/village as a separate form of settlement. Formally, these quasi-formations are not strictly defined, but factually exist. Among them there are city agglomerations, conurbations, other informal unions of localities formed for the solution of some local problems as well as for the coordination of goals and directions of the territory complex development.

Such coexistence of adjacent territories and localities induces to the search of approaches and solutions for the utilization of possibilities for economic development of these localities within a mutual platform of their interests and joint overcoming of barriers on this way.

The goals of the article are to analyze the examples of Lviv region local communities' partnership for the attraction and servicing tourists' flows and to identify the barriers for spreading out the practice of joint efforts of local communities in tourism industry development. Particular attention will be paid to the problem of residents' acquaintance with local places of tourist interest. The study is conducted on the illustrations from Lviv region.

\section{Tourism as the main factor of the local development}

Tourism frequently becomes a leverage, the application of which enables to renovate a local economy and the economy of a whole country. Tourism plays a significant role in the formation of gross domestic product, the creation of more jobs and providing 
employment, and the external trade balance enhancement for some countries, regions, and local communities. Tourism considerably affects such key economic sectors as transport and communication, construction, agriculture, production of consumer goods, and others, so it is a peculiar catalyst of the social and economic development.

A local authority along with direct actors of the tourism market (tourism agencies, tour operators, hotels, entertainment and wellness centers etc.) is also interested in the attraction of tourists to a territory of a locality, because such involvement may conduce to the fulfillment of local budgets and the employment of a considerable share of the population.

However, conditions of the tourism development in Ukraine, including a non-balanced social and economic situation in the country, a non-regulated character of tourism industry encouragement mechanisms, absence of an effective development strategy for this sector at the national as well as at regional levels do not allow to use a positive (system-creating) impact of the sector on the development of a majority of Ukrainian regions and the national economy in general (Kamushkov, 2010, p. 3).

The escalation of these problems has basically two vectors of causes of their arising: on the one hand, there is insufficient social and economic development of the regions and local authorities are not able to support tourism development in the controlled territory through the formation of a conducive business environment for business entities in the sector on their own; on the other hand, business entities are not able to compete with foreign tourism firms and to develop internal (incoming) tourism, to earn adherence of Ukrainian and foreign tourists (Vynogradova and Darchuk, 2013, p. 183-191).

In 2013, Ukraine has taken 76th place among 140 countries (85th place among 139 countries in 2011) in the ranking of competitiveness of countries in the tourism sector according to the Davos World Economic Forum method (Travel and Tourism Competitiveness Report, 2013, p. xvi). Such a low position is primarily due to low rates (99th place) for human, cultural and natural resources (Travel and Tourism Competitiveness Report, 2013, p. xviii).

Of course, the tourism attractiveness of different parts of Ukraine is not the same. Thus, Lviv region is unambiguously reported to be one of regions possessing the significant and diversified potential for the tourism development. A touristic character of Lviv region is determined by many peculiarities. One of them is a convenient and favorable geographical and transport location, because Lviv region is the transit area to European countries for Ukraine. The national and ethnic mix of the region creates original ethnographical culture. In addition to Ukrainian culture, there are wonderful monuments of Polish, Armenian and Austrian cultures included in the UNESCO World Heritage List. The fusion of cultural traditions also took place. Lviv region has a relatively conducive ecological situation, a relatively low level of territory industrialization, sources of the medicinal water and mud, national natural parks that enables development of medical and recreation tourism. The distribution of tourist sites in the region allows to organize tourist journeys lasting 1-2 days, including trips to adjacent regions. 
Working out in detail the abovementioned information, it is worth mentioning that Lviv region takes one of the leading places in the country in availability of natural and recreational resources: they account for approximately $5.4 \%$ of the Ukrainian natural and recreational potential. The Lviv region's natural and recreational potential is presented by the medicinal mineral water, medicinal mud, earth wax, climate, water, and forest resources. Remarkably, the Ukrainian natural resources are little-known in the world, since they take only 102nd place in the tourism competitiveness ranking (Travel and Tourism Competitiveness Report, 2013, p. 41).

During the last decade, an amount of tourism services provided by tourism companies of Lviv region has increased 10 times. During the previous three years the number of tourists has increased by $51 \%$ (168,400 persons), a number of foreign tourists has increased by $70 \%$ (16,300 persons), a number of trip participators has increased by $19 \%$ (94,500 persons), the amount of tourist services have increased by $160 \%$, and payments to the budget have increased by 50\% (Statistical Yearbook of Ukraine, 2014).

Because of the permanent increase of the amount of both foreign and domestic tourists, a number of hotels and places of temporary accommodation in the region has grown from 115 in 2009 to 307 in 2013 (Statistical Yearbook of Ukraine, 2014).

The attractiveness of tourism industry is not only visible in Lviv region. A considerable amount of localities and regions (Figure 1) choose tourism as a prior direction of their development. After analyzing 47 visions and missions of small and medium-sized cities development strategic plans in Ukraine, it was found that the greatest attention by the creators of these documents focused on economy, culture, and tourism. Nevertheless, considering the abovementioned tourism competitiveness ranking (Travel and Tourism Competitiveness Report, 2013, p. 347), a position of the attitude of the Ukrainian population to foreign tourists was evaluated by international experts and ranked 127th among 140 countries in 2013.

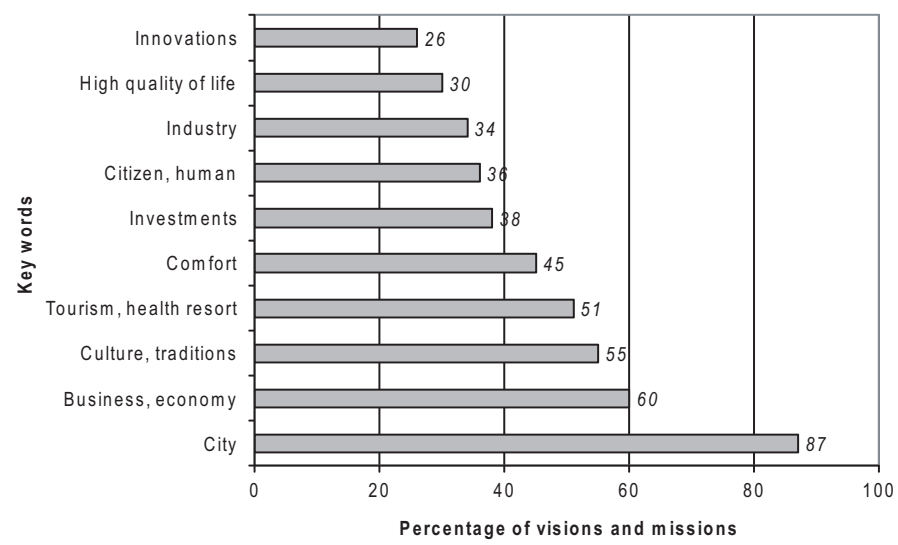

Figure 1. The most common words in the visions and missions of small and medium-sized cities development strategic plans 
Kotler notices that a territory's potential depends to a lesser degree on location, climate and natural resources than it does on human will, skill, energy, values, and organization (Kotler et al., 2005, p. 47).

The tourism sector development process occurs non-uniformly even in one region. The cause of this is not always a different initial position of the tourism infrastructure development in a locality. This stipulates scientific and applied interest in the determination of a possible influence level of a local authority and a community on the tourism development in their locality. The scientific interest is also concerned with a partnership role of local communities in the attraction and servicing tourists' flows.

The review of the recent literature on the subject of research shows that the overall tourism attractiveness of a destination depends on the relationship between the availability of existing attractions and the perceived importance of such attractions (the perceived ability of destinations to satisfy tourists' needs) (Marino, 2015, pp. 23-29; Mikulić et al., 2015; Lemaire, Viassone, 2015, pp. 30-38; Della Corte et al., 2015, pp. 39-50; Smith, 2014; Sharpley, Telfer, 2014). Nevertheless, despite the collaboration problems of local communities in creating mutual tourism products and forming their attractiveness (Collaboration in Tourism Businesses and Destinations, 2015; Ezeuduji, 2015, pp. 212-228; Man, Zhang, 2015, pp. 757-760) as well as the issues of resident's attitudes to tourism (Chandralal, 2010, pp. 41-49; Mason, 2000, pp. 391-411) are actively discussed in the literature, the problems of recognition and understanding of tourism potential of a region by local population is not presented enough.

\section{Methodology of the research}

This paper includes a review of the literature focused on the practice of collaborative approaches to creation of mutual tourism products by several local communities or territories. The factors relating to economic need of such activities are also discussed. The main concern is directed to such a factor as the local population's understanding of attractiveness of tourism and recreational facilities in their region. To gather necessary information, the survey was conducted by the authors. The inhabitants of Lviv region were surveyed. The sampling was formed with the use of the quota method. Its structure disclosed the allocation of respondents to integrated groups according to a living area property. A sampling amount accounting for 350 persons provides the reliability of the received results with the $95 \%$ probability and within a 3-5\% deviation. The research was conducted in September - October 2014 with the use of printed questionnaires, which were filled in by respondents. 


\section{Formation of a mutual tourism product of a territory}

As previously mentioned, Lviv region has considerable tourism and recreational potential as an integral unity and is competitive on national as well as international scale. Nevertheless, the development of economic activities related to the usage of this potential frequently has a non-system and desultory character. In this case, we do not mean the presence of structural disproportions of state and local agencies attention regarding some types of tourism/recreation or the development of tourism infrastructures of some localities or territories while underfunding the others. Although such problems also exist, in this case we use the term "non-system" to describe non-concordance/incoherence of actions between representatives of certain local communities, which dispose objects being potentially attractive for tourists.

In fact, local communities of certain small and medium towns or villages attempt to develop and promote their tourism or recreational facilities on their own. However, the return of such efforts is inconsiderable or it is equal to zero, at least in an economic dimension, i.e. increase in business activity of economic entities being directly or indirectly involved in the tourism and recreational sector, growth of incomings to a local budget, etc.

In addition, such a result is a consequence of insufficient attempts in a situation, when a locality expects to be noticed by the external environment, e.g. tourism companies, certain tourists, and other market actors. Not only are the towns of Olesko, Zolochiv, Drohobych, etc. famous for their tourism facilities and the towns of Truskavets, Velykyi Liubin, etc. for recreational facilities, but there is a considerable number of towns and villages in Lviv region with potentials in these sectors commensurable with the mentioned examples and sometimes even more significant. Unfortunately, these localities are not known to the public as tourist or recreational facilities.

Another cause of the low return of attempts aimed at the tourism sector development in some small/medium towns is the local potential assessment bias. In other words, one or other tourism/recreational objects located within a certain town/village are not of sufficient real importance for potential visitors. Simultaneously, following a general tendency and simplified perception of the environment, local decision leaders determine tourism as one of the so-called "points of growth" in the formation of directions of the future development of a local community. In such terms, there is an obvious situation of the improper estimation of an internal environment in the determined context (namely, in the context of tourism and recreation). Consequently, it results in the dissipation of local resources and the activity efficiency decrease related to strategic management of the territory development.

Different objects, including objects of natural origin being known in the country as well as abroad, are deployed in the territories of Lviv region localities. Almost always tour operators include viewing such Lviv region sights as the Central part of the town of Zhovkva, Oleskyi and Zolochivskyi castles, castles in Stare Selo, Zvenyhorod, etc. in a standard trip program. Simultaneously, in any of the mentioned 
cases we cannot recognize a finished tourism product providing its customer with complex hotel and restaurant servicing, trade companies, leisure companies, and vital facilities for a longer stay (more than 1 day).

An instance of the pragmatic approach to the mutual usage of local tourism opportunities is the cooperation between Novyi Rozdol, Mykolaiiv, and Zhydachiv (all of them are towns of Lviv region). Such institutionally improved cooperation (this sub-region is served by a single agency of local development) contemplates the mutual tourism product development. Festival tourism, which is popular in Lviv region and profitable especially for small and medium-sized business, has been chosen as one of directions of the mutual tourism product (Скоординовані культурні фестивалі, 2014). The agency specially develops unified nameplates of streets and monuments and forms new regional tourist routes to any taste. Except traditional recreational and sacral footpaths, the agency suggests to propose paths in the Second World War battle areas and paths in areas of memorials and soldier entombments that are notable within the sub-region. In such a way, local communities do not only carry infrastructural costs for serving tourists but also provide enough time to make tourists spend their money on this territory (Міжмуніципальна співпраця, 2014).

Exactly in this context, tourism as a local economy sector has prospects of providing considerable input in the local development. Otherwise, these tourism objects may attract a significant number of visitors, but their value in the economic context will be minimal.

Each of the mentioned circumstances leads to a conclusion that only the combination of attempts of some towns disposing one or other tourism/recreational resources allows to form a multi-element product proposition attractive from the point of view of a certain "effective" tourist/recreant type, that is to say, a person, whose bills for services for a local economy exceed expenses for support and development of a respective infrastructure. Furthermore, both internal (the Lviv region population) and external audiences should be considered as potential customers of the tourism product.

A research direction, which is related to the acquaintance of the local population with tourism and recreational facilities of the region and their attitude to the usage of these facilities in the attraction of outside visitors, should be examined in the mentioned context.

\section{Determination of tourism and recreational facilities of Lviv region attractive for internal and external customers}

The examination of attitude of the region inhabitants to tourists was one of the survey's tasks. This enables to determine their potential antagonism, which can be a serious internal threat for the development of the tourism and recreational sectors in the region. 
The region's inhabitants have mainly positive attitudes towards visitants/tourists: such a position was confirmed by $86 \%$ of the participants. Such a situation should be perceived as an internal territory resource because the first impression, which visitants have on a trip, is the attitude of inhabitants towards them and the willingness to help. Later, this impression will be a considerable part of information shared among tourists as they return home.

To complement the previous question, we calculated data explaining the acquaintance of the local inhabitants with the tourism and recreational potential of the region (Figure 2). From this viewpoint, the local population is considered as potential customers of services proposed by companies of the region.

(a)

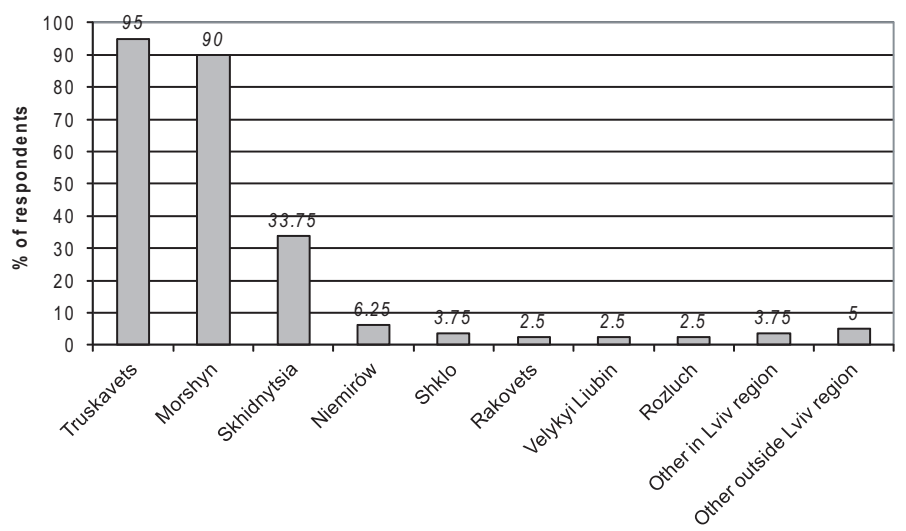

(b)

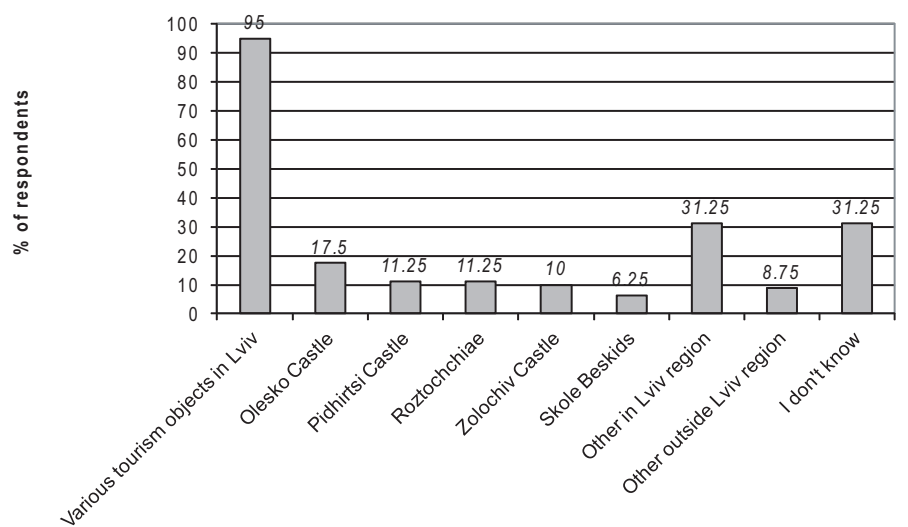

Figure 2. The awareness level of residents with recreation resorts

(a) and travel destinations (b) in the region

Source: own research

As can be seen from Figure 2a, the acquaintance of the inhabitants with the region recreational potential is factually limited by the 2-3 main balneological resorts. At the same time, facilities offered by sanatoriums of such towns/villages as Shklo, 
Nemyriv, Velykyi Liubin, etc. remain little-known. It is worth mentioning that exactly these resorts have a rich history and were well-known outside Ukraine formerly.

A situation regarding the level of acquaintance with natural and historical and cultural monuments of the region, which are objects of tourism interest, is more uniform. Among places with highly assessed potential tourism attractiveness, experts mention approximately ten of those being internationally recognized: Lviv city center, the castles of "Golden Horseshoe of Lviv Region", Shevchenkivskyi Hai, Sokolivski Beskydy, etc.

Nevertheless, a mutual property of both situations described in Figure 2 is a relatively low level of the acquaintance of the Lviv region inhabitants with opportunities, which can be used in having a rest within a living area or near it. Thus, the local inhabitants are a significant reserve of the increase of demand for tourism and recreational services of regional companies. This assertion obtains special topicality under contemporary conditions, which are characterized by new geopolitical realities. As a result, these conditions form extra chances for the development of such tourism regions as Lviv region.

Another conclusion to be drawn from the analysis of the survey results is the "lack of independence" of mentioned settlements in offers of tourism services to potential visitors. Even in the case of balneological resorts as Morshyn, Truskavets etc., they are unable to offer such a wide range of proposals that would be able to fill the entire volume of free time which visitors have. For example, there is a classic situation when vacationers of mentioned resorts devote pre-scheduled time to organized (and not only) tourist trips to tourist attractive places nearby.

It is a visible illustration of "consumption" of mutual tourism product of Lviv region that is offered by a set of settlements. Coordination, joint efforts of certain

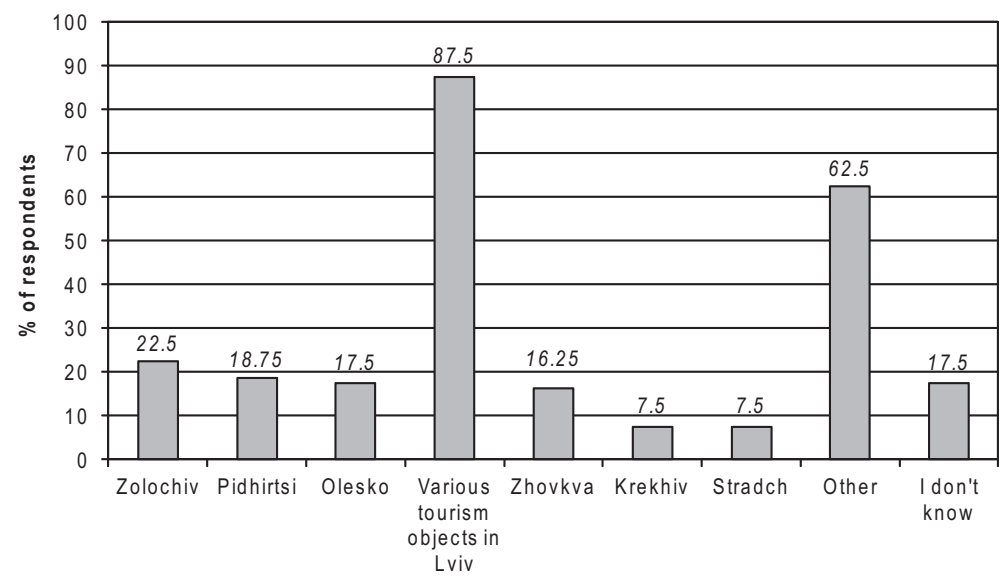

Figure 3. Evaluation of individual settlements of Lviv region from the point of view of their potential interest for tourists 
local communities during the formation of such a product increases its attractiveness in the eyes of potential "customers", in the minds of which Lviv region would be perceived as an area with rich proposals for tourism-recreational services for every taste.

Not only was the internal demand for tourism and recreational services estimated, but also levels of the potential attractiveness of settlements for tourists from other regions of Ukraine and for foreign tourists were ranked (Figure 3).

Results of answers for the question asked allow to stratify the integral tourism product of Lviv region into certain components/sub-products. As it can be seen from Figure 3, this tourism product contains: objects which are conditionally united in the form of "Golden Horseshoe of Lviv Region"; objects of sacral art; balneological resorts; specialized tourism and resort complexes; and a wide range of religious tourism objects. A target audience for each of the mentioned objects is not related to a certain territory. Only Stradch, i.e. religious tourism, is specific. Taking into consideration local peculiarities, inhabitants of the west of Ukraine should be considered as a target audience of religious tourism first of all.

\section{Conclusions}

Unlike many countries, where the inter-municipal cooperation is an ordinary occurrence, it is not a typical and widespread practice for Ukraine. Ukrainian local authorities have been not already endowed with a sufficient amount of legal and financial powers for the effective cooperation. Furthermore, they frequently compete for resources or investments. Nevertheless, model examples of cooperation initiatives emerging recently allow to consider forecasts concerning the further extension of such a practice with careful optimism.

Lviv region has huge tourism potential, but despite positive attitude to visitants/ tourists by the Lviv region inhabitants, they are not well acquainted with places of interests for tourists. Usually residents can mention only $2-3$ balneological resorts and city of Lviv in the region that has hundreds of monuments in UNESCO and national heritage lists, many resort and national parks and organizes numerous international festivals and events.

The survey's results also show that most people in the region do not understand what can be interesting in their localities for tourists and don't see such interesting things in the neighboring territories (excluding Lviv city). Such low level of self-evaluation in communities does not support promotion and high prices for local tourism products. 


\section{References}

1. Виноградова О.В., Дарчук В.Г. Проблеми та стратегічні пріоритети розвитку сільського (зеленого) туризму в Украӥні: регіональний аспект, Проблеми економіки, 2013, №. 4.

2. Звягина Е.С.; Исмаилова А.З. Особенности современного международно-правового регулирувания - как основы сотрудничества в сфере туризма, Научный вестник МГИИ, 2014, №. 4.

3. Камушков О.С. Управління розвитком туристичної сфери України, Класичний приватний університет, Zaporizhia, 2010.

4. Котлер Ф., Асплунд К., Рейн И., Хайдер Д., Маркетинг мест. Привлечение инвестииий, предприятий, жителей и туристов в города, коммуны, регионы и страны Европы, Стокгольмская школа экономики, Saint Petersburg, 2005.

5. Котова Н.Н., Валещук М.В. Институииональные условия индустрии туризма (национальный и региональный acnекты), Управление экономическими системами: электронный научный журнал, 2014, №. 10.

6. Міжмуніципальна співпраця. Одному місту добре, а трьом краще, 2014. Retrieved from http:// www.mled.org.ua/images/stories/files/best-practices/bp_1_cluster_cooperation_feb2014_ukr.pdf

7. Орджоникидзе М.М. Актуальные аспекты стратегического управления региональным туризмом, Известия Санкт-Петербургского государственного экономического университета, 2011, №. 2.

8. Саак А.Э., Жертовская Е.В., Управление развитием туристського комплекса муниципального образования, Инфра-M, Moskva, 2012.

9. Скоординовані культурні фестивалі - інструмент залучення туристів та основа місцевого економічного розвитку у Львівській області, 2013. Retrieved from http://www.mled.org.ua/images/ stories/files/Success_Stories/ss\%202_rozdillya_festivals_ukr.pdf

10. Статистичний щорічник України, 2013. Retrieved from http://ukrstat.org/uk/druk/publicat/kat_u/ publ1_u.htm

11. Chandralal, K.P.L., Impacts of tourism and community attitude towards tourism: a case study in Sri Lanka, South Asian Journal of Tourism and Heritage, 2010, Vol. 3, No. 2.

12. Della Corte V., Sciarelli M., Cascella C., Del Gaudio G., Customer satisfaction in tourist destination: The case of tourism offer in the city of Naples, Journal of Investment and Management, 2015, Vol. 4, No. 1.

13. Ezeuduji I.O., Strategic event-based rural tourism development for sub-Saharan Africa, Current Issues in Tourism, 2015, Vol. 18, Issue 3.

http://dx.doi.org/10.1080/13683500.2013.787049

14. Gursoy D., Saayman M., Sotiriadis M.D. (ed.), Collaboration in Tourism Businesses and Destinations: A Handbook, Emerald Group Publishing, Bingley, 2015.

15. Lemaire J.-P., Viassone M., Tourist destinations positioning: From indexes to managerial implications, Journal of Investment and Management, 2015, Vol. 4, No. 1.

16. Man D., Zhang H. Tourism Complex in the Perspective of Tourism Clusters, Eastern Academic Forum, 2015.

17. Marino A., "Total Attractiveness" for Consumer in advanced D.D.-B.B. Systemic Marketing in Tourism Management, Journal of Investment and Management. Special Issue: Attractiveness and Governance of Tourist Destinations, 2015, No. 11.

18. Mason, P., Resident's attitudes to proposed tourism development, Annals of Tourism Research, 2000, Vol. 27, No. 2.

19. Mikulić J., Krešić D., Miličević K., Šerić M., Curković B., Destination Attractiveness Drivers among Urban Hostel Tourists: An Analysis of Frustrators and Delighters, International Journal of Tourism Research, 2015. http://dx.doi.org/10.1002/jtr.2034

20. Sharpley R., Telfer D.J., Tourism and Development: Concepts and Issues, Channel View Publications, Bristol, 2014.

21. Smith S., Tourism Analysis: A Handbook, Routledge, London, 2014.

22. Travel and Tourism Competitiveness Report, 2013. Retrieved from http://www3.weforum.org/docs/ WEF_TT_Competitiveness_Report_2013.pdf 


\section{Problems and Prospects of the Formation of a Mutual Tourism Product of Local Communities}

Abstract. The article highlights the problems and prospects of the common mutual tourism product of local communities on the example of Lviv region. The study proves the significance of tourism as a leading factor in local development, highlights the practical necessity of the mutual tourism product for local communities. The results of the survey that determines the tourist and recreational facilities in Lviv region, which are attractive for domestic and foreign customers, are analyzed as well.

\section{Problemy i perspektywy powstania wspólnych produktów turystycznych dla lokalnych społeczności}

Abstrakt. Artykuł opisuje problemy i perspektywy związane z powstaniem wspólnych produktów turystycznych lokalnych społeczności na przykładzie Lwowa. Praca pokazuje jak ważna jest turystyka jako czynnik lokalnego rozwoju i podkreśla potrzebę wypracowania przez lokalne społeczności wspólnych produktów dla turystów. W artykule analizowane są także wyniki ankiety wskazujące ośrodki turystyczne i rekreacyjne w pobliżu Lwowa atrakcyjne zarówno dla turystów krajowych, jak i zagranicznych. 